University of Nebraska - Lincoln

DigitalCommons@University of Nebraska - Lincoln

USDA Wildlife Services - Staff Publications

U.S. Department of Agriculture: Animal and Plant Health Inspection Service

April 2000

Immunocontraception of White-Tailed Deer with GnRH Vaccine

Lowell A. Miller

National Wildlife Research Center

Brad E. Johns

National Wildlife Research Center

Gary J. Killian

Pennsylvania State University, University Park, Pennsylvania

Follow this and additional works at: https://digitalcommons.unl.edu/icwdm_usdanwrc

Part of the Environmental Sciences Commons

Miller, Lowell A.; Johns, Brad E.; and Killian, Gary J., "Immunocontraception of White-Tailed Deer with GnRH Vaccine" (2000). USDA Wildlife Services - Staff Publications. 640.

https://digitalcommons.unl.edu/icwdm_usdanwrc/640

This Article is brought to you for free and open access by the U.S. Department of Agriculture: Animal and Plant Health Inspection Service at DigitalCommons@University of Nebraska - Lincoln. It has been accepted for inclusion in USDA Wildlife Services - Staff Publications by an authorized administrator of DigitalCommons@University of Nebraska - Lincoln. 


\title{
Immunocontraception of White-Tailed Deer with GnRH Vaccine
}

\author{
Lowell A. Miller, Brad E. Johns, Gary J. Killian
}

Miller LA, Johns BE, Killian GJ. Immunocontraception of white-tailed deer with GnRH vaccine. AJRI 2000; 44:266-274 (C) Munksgaard, Copenhagen

PROBLEM: Reduction of excess numbers of white-tailed deer (Odocoileus virginianus) is an example of a potential use for immunocontraception as a means of wildlife population management.

METHOD OF STUDY: A 4 year multifaceted study was conducted to determine the long term effects of gonadotropin releasing hormone $(\mathrm{GnRH})$ contraceptive vaccine on the fertility and behavior of female and male white-tailed deer. Deer were monitored for breeding behavior, hormone levels, pregnancy, fawning and GnRH specific antibody levels.

RESULTS: Treatment lead to reduced fawning rates, altered estrus behavior, reduced concentrations of progesterone, contraception and failure to maintain pregnancy following conception. GnRH immunized does bred to untreated bucks had an $88 \%$ reduction in fawning caused by either immunocontraception or immunocontragestion. The vaccine effect is reversible, directly related to the antibody titer. Infertility lasted up to two years without boosting. GnRH immunized bucks demonstrated no interest in sexual activity when paired with control females. Depending on the immunization schedule, antlers either dropped early or remained in velvet.

CONCLUSIONS: The results of this study demonstrate that GnRH vaccine is effective in inducing a reversible infertility in white-tailed deer, the infertility lasting up to two years without boosting.

\section{INTRODUCTION}

One of the most successful immunocontraceptive vaccines used for wildlife is porcine zona pellucida (PZP). Several authors have published on the use of PZP immunocontraceptive vaccines to immunosterilize white-tailed deer. ${ }^{1-3}$ This is the first long term study of the use of GnRH contraception of deer. This GnRH immunocontraceptive study was part of a multi-year WhiteTailed deer infertility study on the deer herd at Pennsylvania State University, (PSU) University Park, Pennsylvania in cooperation with National Wildlife Research Center, (NWRC) Fort Collins, CO.
Key words:

Gonadotropin releasing hormone, immunocontraception, immunocontragestion, white-tailed deer

LOWELL A. MILLER

BRAD E. JOHNS

National Wildlife research Center, 4101 Laporte Avenue, Fort Collins, Colorado 80521, USA

\section{GARY J. KILLIAN}

Pennsylvania State University, University Park, Pennsylvania 16802, USA

Address reprint requests to Lowell A. Miller.

USDA/National Wildlife Research Center, 4101 Laporte Ave., Fort Collins, CO 80521, USA.

E-mail: lowell.a.miller@usda.gov

Submitted August 30, 1999; accepted January 30, 2000. 
The effects of immunizing white-tailed deer with GnRH on reproductive rates, behavior and physiology was studied. Since GnRH affects the reproductivity of both the male and female, one of the effects of particular interest was the effect of GnRH antibody on antler development. GnRH controls the level of testosterone, which in turn controls when bucks rub off the velvet covering, exposing the hardened antlers in the fall and separation of the antler from the pedicel and subsequent shedding of the antlers in the spring. ${ }^{4-6}$

Immunization against GnRH prevents circulating GnRH from binding to pituitary receptors and therefore blocks release of the two gonadotropins follicle stimulating hormone (FSH) and luteinizing hormone (LH). ${ }^{7}$ The reduction or absence of serum FSH and LH leads to atrophy of the gonads and concomitant infertility in both sexes, effecting a non-surgical castration in animals.

Immunization with GnRH appears to be highly specific, and does not appear to affect other hypothalamic releasing hormones. Awoniyi et $\mathrm{al}^{8}{ }^{8}$ demonstrated that GnRH immunized rats failed to release FSH and LH, but that other pituitary hormones and their vital non-sexual functions were not impaired.

GnRH contraceptive vaccines have been evaluated as immunocastration agents in pets, ${ }^{9}$ cattle, ${ }^{10,11}$ horses, ${ }^{12}$ sheep, ${ }^{13}$ and swine. ${ }^{14}$ Recently, in studies with Norway rats, ${ }^{15}$ we found that both males and females immunized with a GnRH vaccine were $100 \%$ infertile. Given these impressive results and the highly specific target of the GnRH vaccine, it was decided to evaluate the efficacy of a GnRH contraceptive vaccine in white-tailed deer. The objectives of this study were to administer the GnRH vaccine to male and female deer to determine its effectiveness in reducing fertility and evaluate its general impact on the physiology of reproduction in order to better understand the vaccine's mechanism of action.

\section{MATERIALS AND METHODS}

\section{GnRH Antigen Preparation}

The 10 amino acid GnRH, which is conserved among all mammals, was made immunogenic by coupling to the carrier keyhole limpet hemocyanin (KLH). The GnRH used in this study was synthesized at Macromolecular Resources, Colorado State University (Ft. Collins, CO) with the structure [pEHWSYGLRPGGC-SH]. A glycine was added at the $\mathrm{C}$ terminus as a spacer and a cysteine was added to provide a coupling agent to maleimide on KLH. This design also insured that coupling only occurred at the $\mathrm{C}$ terminus end of GnRH. The underlined amino acids represent the native GnRH molecule. ${ }^{16-19}$

This GnRH analogue, called GnRH-glycys ${ }^{17}$ apparently has a similar conformation to native GnRH. ${ }^{20}$ Maleimide-activated KLH was purchased from Pierce Chemical Co. (Rockford, IL), and the C-terminal Cys-GnRH was coupled to the activated KLH using the method described by the manufacturer. Briefly, both KLH-maleimide and the peptide were lyophilized. For coupling both of the reagents were rehydrated and immediately mixed together in a $1: 1$ w:w ratio. The reaction was allowed to proceed for 2 $\mathrm{hr}$ at room temperature. Free peptides were separated from the preparation using a G-25 sephadex column. The void volumn off the column, containing KLH$\mathrm{GnRH}$, was use for the vaccine.

\section{Animals Used and Immunization Schedule}

The animals in the study were in a 17 acre fenced facility containing several paddocks for separation of study groups. The facility has holding pens and shoots which allow the deer to be accessed for injection and blood draws.

In this 4 year study on the effectiveness of KLHGnRH vaccine to immunocontracept deer, eight fertile does and four fertile bucks were injected subcutaneously with one primary immunization followed later by booster doses all containing $1 \mathrm{~mL}$ of vaccine distributed among several sites at the center of the back between the scapulae. All deer received a prime dose containing $500 \mu \mathrm{g}$ of KLH-GnRH in saline mixed 1:1 with complete Freund's adjuvant (CFA) and approximently 1 month later were given a boost containing $300 \mu \mathrm{g}$ of KLH-GnRH mixed 1:1 with incomplete Freund's adjuvant (IFA). Additional boost injections were given on a yearly basis depending on the current antibody titer. Fawning results of the GnRH-treated does were compared to the fawning rates of sham (saline mixed with Freund's adjuvant) treated does and fawning of the does from the herd not involved in the study.

\section{Measurements of Vaccine Effectiveness}

The biological effects of the GnRH vaccine were measured by: (1) The immune response to the vaccine by measuring the specific antibody to $\mathrm{GnRH}$, (2) Determining the blocking effect of the GnRH antibody by measuring the reduction in serum progesterone concentrations in the does and testosterone concentrations in the bucks, (3) Use of ultrasound in February, and palpation in April as a measure of pregnancy and maintaince of pregnancy, (4) Behavioral responses during the rut period to insure that any change in behavior in not detrimental to the deer. 
(5) Natality responses, as it is the ultimate result of the contraceptive treatment.

Blood samples were taken immediately before the prime injection, immediately before each boost, and several times throughout the fall and winter. Blood serum samples were analyzed for immune response by ELISA and tested for progesterone or testosterone by RIA.

Normally, the does from this herd become pregnant in November or December; therefore, to differentiate between failure to conceive and failure of fetal maintenance, trans-rectal ultrasound was performed in late January or early February to detect placental cotyledons (plascentomes) or fetuses. ${ }^{21}$ Because it is known that progesterone is needed for maintenance of pregnancy, ${ }^{22-25}$ blood was drawn the same day of the ultrasound and tested for serum progesterone concentration levels. Fetal development was monitored in the does by palpating the abdomen externally between late April and mid May. The results of these early detection techniques were compared with fawning to determine if evidence existed for the death and resorption of the fetus during gestation. ${ }^{26}$

In the ELISA test used to assess the immune response to the GnRH vaccine, a 96-well plate was prepared by adding $100 \mathrm{ng}$ of BSA-GnRH antigen to each well and blocking with PBS-2\% powdered milk. Since KLH-GnRH was used in the vaccine, we used BSA-GnRH on the plate, thus detecting only antibody to GnRH.

Plasma testosterone in the males and plasma progesterone in the females were assayed by the coata-tube RIA method (Diagnostic Products, Los Angeles, CA). Fifty micro liters of serum were used for each assay.

The estrus activity of rutting behavior of the GnRH-treated deer was compared to control deer in the open pen natural setting. Observations were conducted for $2 \mathrm{hr}$ each time, three times daily from November 7 through February 12, and two times daily until February 28. Estrus activity was considered as any of the following behavior of males towards females: vaginal sniffing, pursuit, aggressive guarding, and mounting and copulation.

\section{RESULTS}

\section{Fawning Data}

There was no apparent change in the outward appearance of the treated or control females as the breeding season approached. Behaviorally, the first estrous cycle brought an increased interest in the does by the bucks. The control deer in the study were generally bred the first time they came into estrus. As deter- mined by the fawning dates, breeding was essentially complete during the month of November.

Of the original four does that were immunized with GnRH vaccine and followed for 4 years, two of the four deer remained infertile throughout the study (Fig. 1a, b). Deer number 428 remained infertile without boosting the $3 \mathrm{rd}$ and 4 th years. The antibody titer on deer number 578 began to drop and the deer was boosted. The titer increased after the boost and the deer remained infertile. The antibody titer in deer number 471 was low in the third year, but the deer was not boosted and conceived in the fourth year (Fig. 2a). Deer number 517 died of a treatment unrelated cause in the 2nd year; however, autopsy indicated that she was not pregnant (Fig. 2b). Three fawns were born to these four does during the 4 years, or three fawns/14 doe years (doe years $=$ the number of does times the number years tested), compared to 25 fawns/14 doe years in the control deer during this same period of time.

Of the four additional does given GnRH treatment in the third year, one fawn was born during the first year. With the additional group of does added there were five fawns/24 doe years $(0.21$ fawns/doe/year) as compared with 35 fawns/19 doe years (1.8 fawns/doe/ year) in the sham-treated group. This represents an $88 \%$ reduction $(P<0.01)$ in fawning in the GnRH group compared with the sham controls. The average of $1.7 \mathrm{fawns} / \mathrm{doe} / \mathrm{year}$ is representative of the average reproduction in normal breeding herd at PSU for these 4 years (Table I). Fawns born to the GnRHtreated deer appeared healthy and normal.

\section{Behavioral Observations}

Estrus in the GnRH-treated does as compared to the control does was determined by the sexual interest of the buck in the doe. The most common sexual activity observed was confined to bucks sniffing the does and short pursuits of bucks chasing does. GnRH-treated does were observed having zero to two estrus events with a mean of $0.65 \pm 0.16$ (SE) estrus events for a period of 30 days during the rutting season as compared to the controls which were observed in estrus $0-2$ times with a mean of $0.95 \pm 0.14$ (SE) $(P>0.05)$ estrus event for a period of 44 days during the rutting season.

\section{Antibody Titers}

In the four does treated the first two years, peak antibody titers ranged from 64,000 to 128,000 . These deer demonstrated reduced estrous activity and reduced fertility. The deer with these high titers had negative ultrasound evaluation for pregnancy in late January. (Fig. 1a, b) 
The deer that did not conceive had low serum progesterone concentrations at the time of ultrasound. During the third year, with no boosting, anti-GnRH antibody titers in the three remaining does dropped to $16,000-32,000$ in October and November. Even though all deer had a positive ultrasound indicating the presence of fetuses on February 4, none of the deer fawned. At this time, serum progesterone concentrations were almost non-detectable which is inconsistent with successful pregnancies. Accordingly, palpation for viable fetuses was negative for all three deer in April of this year. (Figs. 1 and 2, year 19961997)

\section{Progesterone Concentrations}

Studies on the control deer suggest serum progesterone in late January to early February is predictive of success or failure of pregnancy. The data suggest that non-pregnant deer have serum progesterone concentration of less than $1.0 \mathrm{ng} / \mathrm{mL}$ and serum progesterone concentrations of $4 \mathrm{ng} / \mathrm{mL}$ or greater correlates with fawning success in the control deer. The treated deer followed the same pattern. During the 4 year study consisting of $22 \mathrm{GnRH}$ doe years, 15 of the February progesterone levels were $1.0 \mathrm{ng} / \mathrm{mL}$ or less and these does failed to fawn. Four had levels greater than $4.0 \mathrm{ng} / \mathrm{mL}$ and produced fawns. The other three (a)

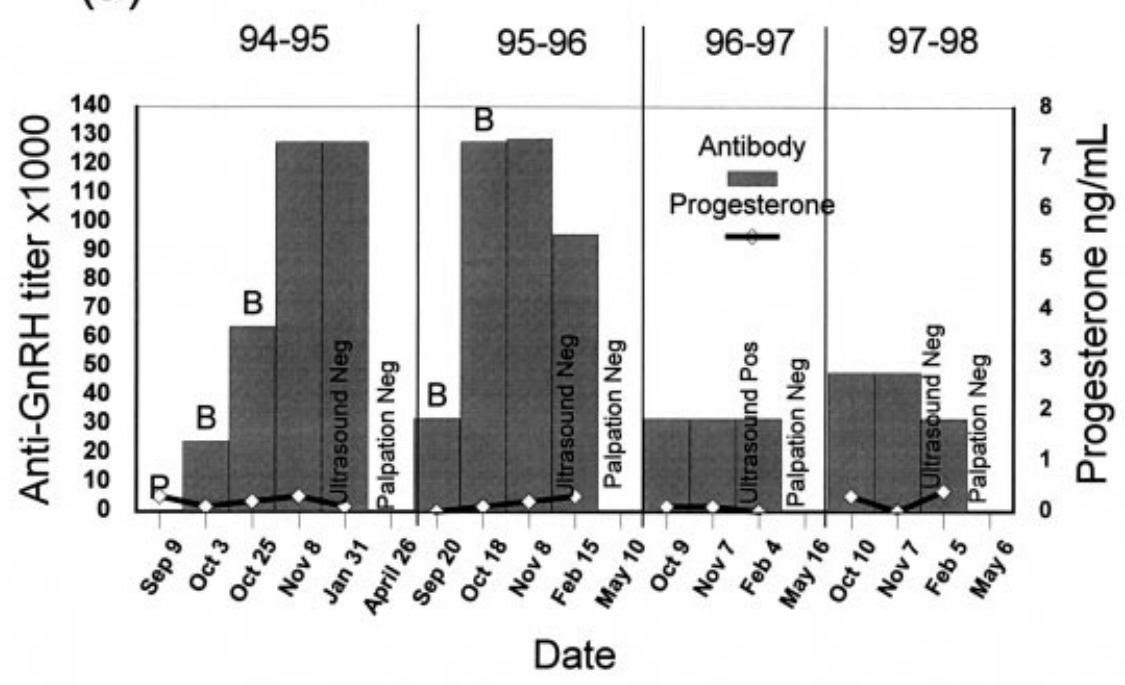

Female Deer KLH-S-C-GnRH

(b)

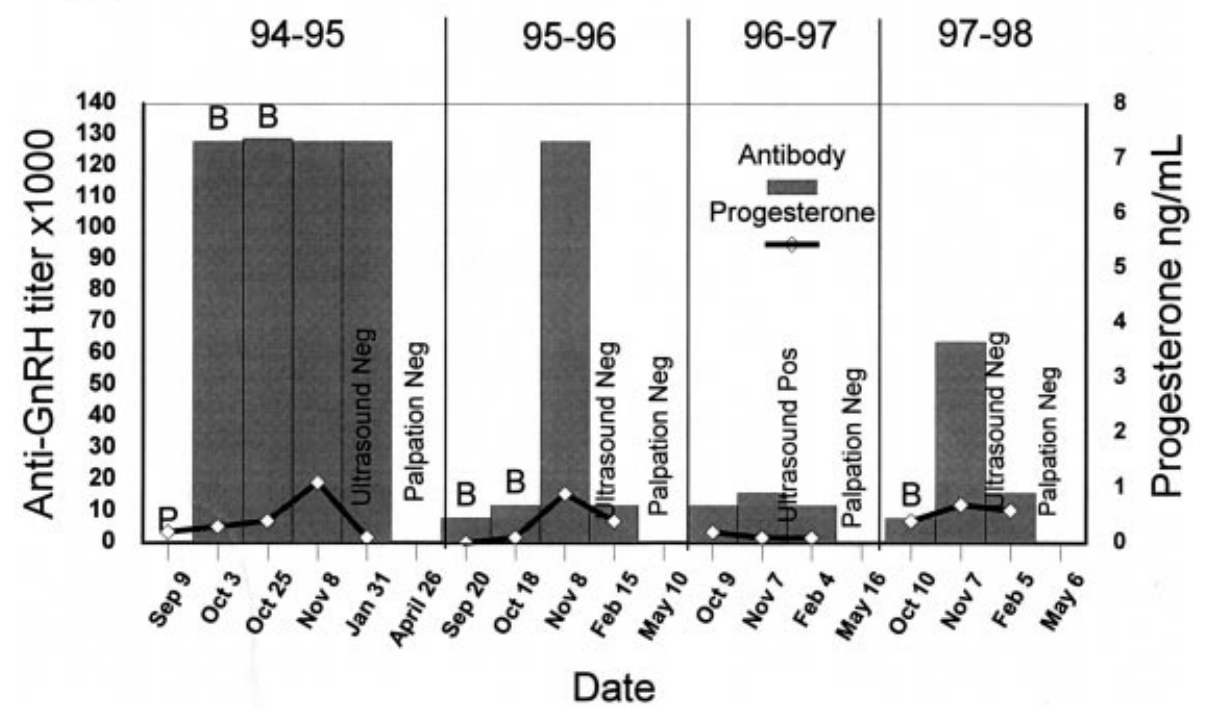

Fig. 1. Correlation between antiGnRH titers, progesterone levels, ultrasound measurements, palpations and fawning. (a) Shows a deer with no fawns for 4 years and not vaccinated the last 2 years. (b) Shows a deer with no fawns for 4 years, however the titer began to drop after the third year and the deer was boosted on the fourth year. 


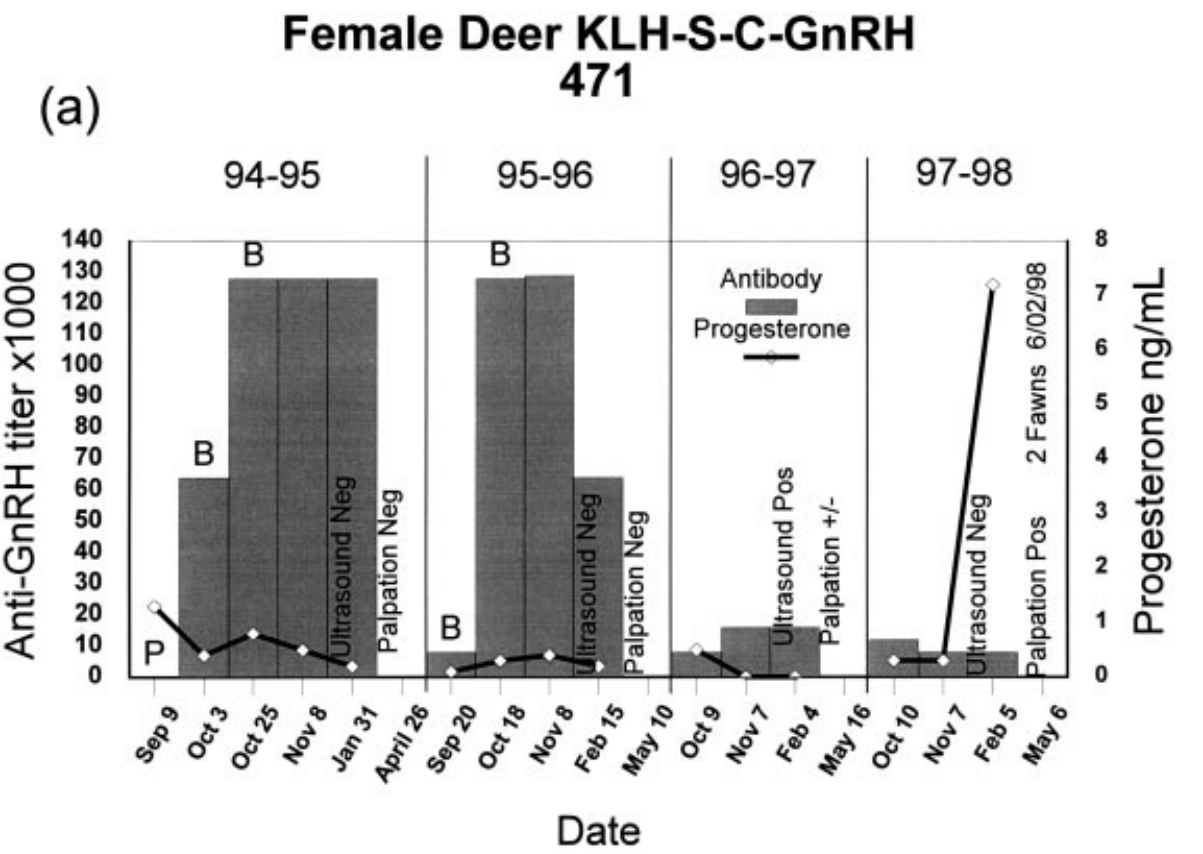

(b) Female Deer KLH-S-C-GnRH

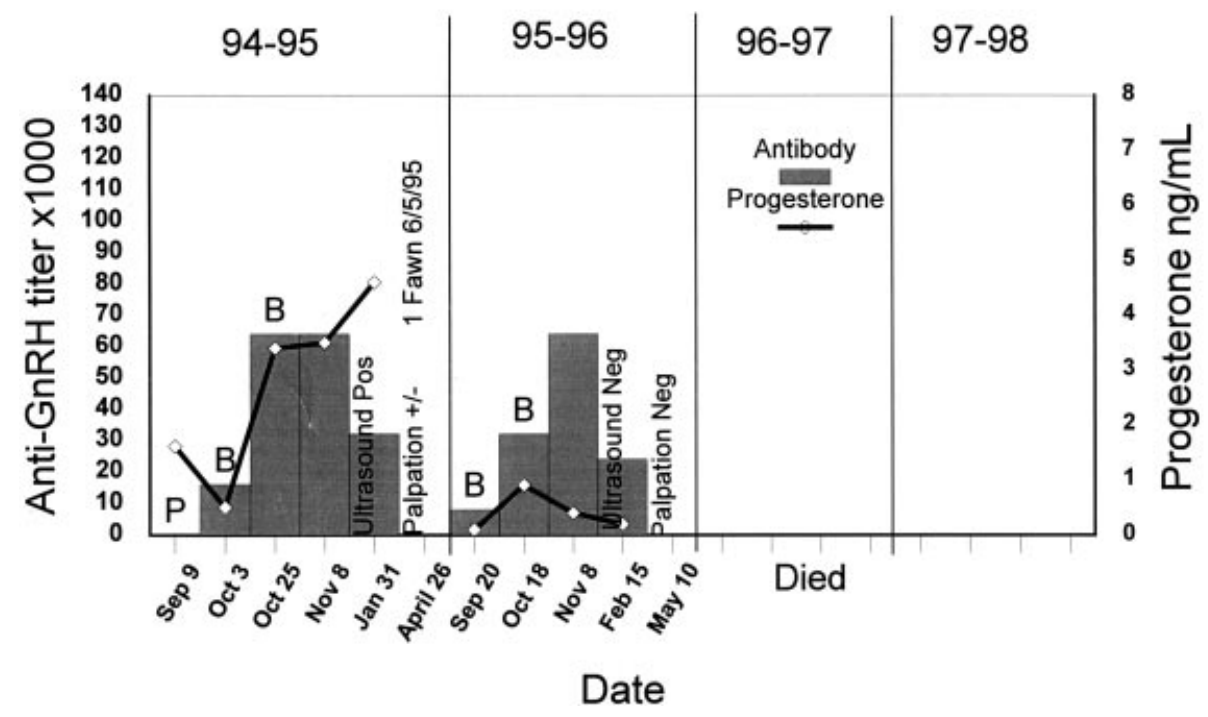

Fig. 2. Correlation between antiGnRH titers, progesterone levels, ultrasound measurements, palpations and fawning. (a) Shows a deer with no fawns for 3 years; however, in year 3, the titer dropped and the ultrasound became positive indicating conception. In this situation, $\mathrm{GnRH}$ acted as a contragestive agent. In the 4th year the deer recovered from the infertility and had two fawns. (b) This GnRH-treated deer was not contracepted the first year, the palpation was questionable because of only one fawn. With a boost the second year, the deer became infertile.

had progesterone levels of 2.2, 2.7 and $3.8 \mathrm{ng} / \mathrm{mL}$ and had positive or questionable ultrasounds but failed to produce a fawn (Figs. 1 and 2).

During the GnRH study, blood was drawn monthly from September or October through the end of January or the beginning of February. In September, before the start of the first estrous cycle of the breeding season, the serum progesterone ranged from $<0.1$ to $1.8 \mathrm{ng} / \mathrm{mL}$. After the beginning of the first cycle, the measured levels of $3.7-11.8 \mathrm{ng} / \mathrm{mL}$ indicate that the deer were in the postovulatory luteal phase of the estrous cycle or that they were pregnant.

\section{Ultrasound and Palpation}

Ultrasound has been shown to be an excellent predictor of early pregnancy. ${ }^{24}$ In control animals, a positive ultrasound observation in late January or early February and a positive palpation in April or May is predictive of fawning. The only exceptions we have noted were when does conceived late in the season; consequently, the ultrasounds and palpations may have been performed too early to detect pregnancy. Compared to control does, the ultrasound and palpation were less accurate at predicting pregnancy in the GnRH-treated does. In the 1996-1997 breeding sea- 
son, 6 of 8 does had a positive ultrasound. However, in both April and May these fawns could not be palpated and none of the 6 does fawned that spring. The 7 th doe had a positive ultrasound palpations were positive, and she gave birth to one fawn in June.

\section{Male Deer}

Control bucks in our study had non-breeding season serum testosterone concentrations of less than 100 $\mathrm{ng} / 100 \mathrm{~mL}$, and developed normal breeding levels of testosterone (350 to $>400 \mathrm{ng} / 100 \mathrm{~mL}$ ) in October and peak breeding activity occurred in November when bucks were introduced to does. Antlers grew slowly early in the summer but rapid growth ensued in August and September. The antlers remained in velvet until September at which time the velvet was rubbed off on nearby trees. The antlers dropped off in March of the following year (Fig. 3a).

The bucks in the GnRH group were treated the first year with a prime dose in September and boosts in October. They lost their already hardened antlers 2 weeks after the second boost (between October 20 28). The testes were less then one half the size of normal bucks. They did not develop the prominent neck musculature normally observed in the fall on mature bucks and therefore looked very much like a doe throughout the breeding season. Treated bucks were penned with untreated cycling does, but demonstrated little sexual interest in the does. Serum testosterone levels for the GnRH-treated bucks ranged from

TABLE I. Summary of Fawns Born in the GnRH Treated Group as Compared to the Sham-Treated Group $(P>0.01)$. Sham Treated Group Demonstrated no Effect as Compared to the Fawning Rate of the Deer Herd not on Study $(P>0.05)$.

\begin{tabular}{lll}
\hline Year & Treatment & Fawns/Does \\
\hline $94-95$ & $\begin{array}{l}\text { Primed \& } \\
\text { boosted } \\
\text { Primed \& } \\
\text { boosted }\end{array}$ & $1 / 4$ \\
$95-96$ & $\begin{array}{l}\text { Boosted } \\
\text { No boost }\end{array}$ & $1 / 8$ \\
$96-97$ & $3 / 8$ \\
$97-98$ & & $156 / 90$ \\
Breeding herd & & $(\bar{x}=1.7)$ \\
& & $35 / 19$ \\
Sham controls & $(\bar{x}=1.8)$ \\
& & $5 / 24$ \\
GnRH-treated & & $(\bar{x}=0.21)$ \\
$=88 \%$ reduction in & & \\
fawns in GnRH group & & \\
\hline
\end{tabular}

(a) 1994-95 Male Control Deer

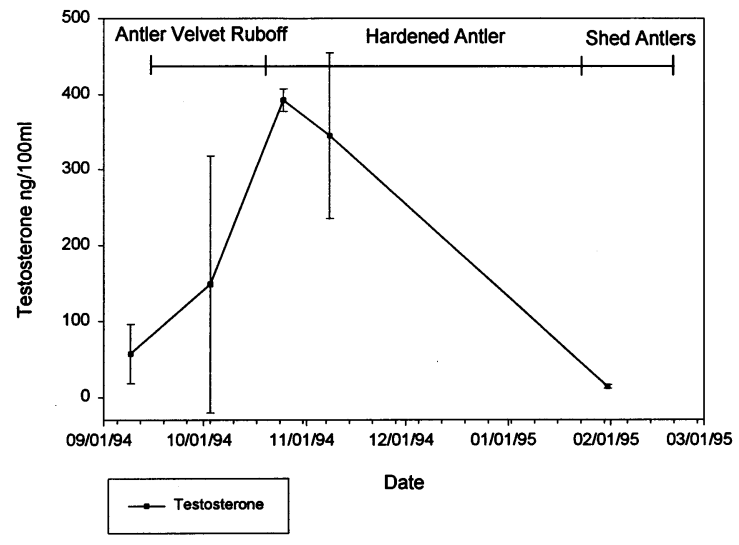

(b)

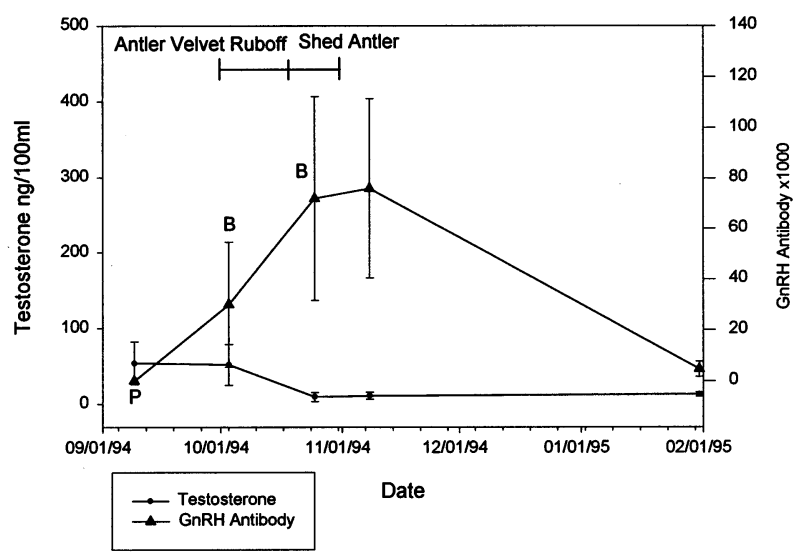

(c)

GnRH Treated Male Deer 1995-96

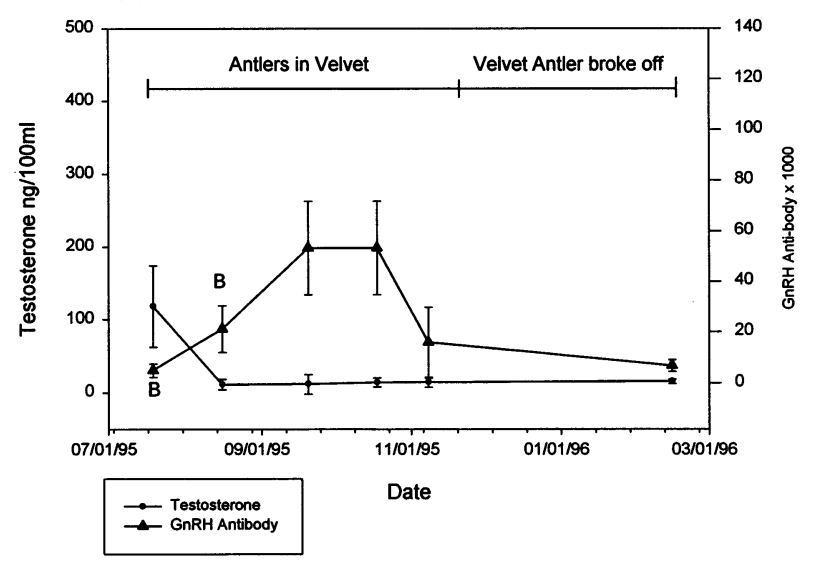

Fig. 3. Relationship between testosterone levels, antler velvet ruboff, shedding of antlers and GnRH antibody titers in the GnRHtreated male deer. (a) Antler velvet rub-off and shedding of antlers correlates with testosterone levels. (b) The rise in anti-GnRH titers suppressed testosterone levels resulting in early shedding of antlers. (c) In the second year, the antlers of the GnRH-treated males remain in velvet because of the low testosterone. These antlers broke off in January. 
11-74 $\mathrm{ng} / 100 \mathrm{~mL}$ throughout the breeding season, which are in the range of non-breeding testosterone concentrations. Antibody titers to $\mathrm{GnRH}$ ranged from 12,000 to 128,000 during the fall period (Fig. 3b).

In the second year, three of the bucks were boosted with the KLH-GnRH vaccine in July and August. The fourth buck died before the start of the second year of research. The anti-GnRH titers peaked in September. The testosterone of these bucks remained less than $30 \mathrm{ng} / 100 \mathrm{~mL}$ throughout the breeding season. In contrast to the first year, the antlers remained in velvet throughout the fall. The antlers never cleaved normally at the base of the pedicel, but instead broke off one to four inches above the pedicel between January 10 and February 13 (Fig. 3c). This breakage was likely a result of freezing temperatures which killed the unhardened antler, thereby resulting in reduced antler strength.

In the third year, the three bucks were not boosted in order to observe the long term effects of the GnRH vaccine. One of the three bucks died in early January, 1997. Histology indicated that testicular regression had occurred in this buck when compared with those of a wild buck killed in late December, 1996. The diameter of the seminiferous tubules of the treated buck were less than $50 \%$ that of the control tissue. In addition, the germinal epithelium of the treated buck only contained spermatogonia in contrast to the control tissue which contained a full complement of cell types including mature spermatids. The treated buck did not appear to be capable of reproduction at the time of death. One of the two remaining bucks did not develop any sexual activity. Serum testosterone was less than $10 \mathrm{ng} / 100 \mathrm{~mL}$, his testicles remained small in size, and the antlers remained in velvet until breaking off 1 inch above the pedicle as in the second year. However, the third buck developed normal sexual activity, including testosterone levels of $300 \mathrm{ng} / 100$ $\mathrm{mL}$, normal testicle size, and normal hardening of the antlers.

The sexual responses of the bucks were directly related to the anti-GnRH titers throughout the 3 years. The bucks that remained sterile had $\mathrm{GnRH}$ titers of $4000-16,000$ as compared to a $1000-2000$ titer in the fertile buck. When the GnRH-treated fertile buck was put in with control females he demonstrated sexual interest in the does in estrous.

\section{DISCUSSION}

\section{Female Deer}

The results of our study indicate the GnRH vaccine is effective in reducing fertility in the doe by either contraception or contragestion. Although all deer re- sponded to the vaccine, variation in antibody titer among deer was noted. Variations in immune response, and resultant differences in reproductive physiology is consistant with past observations in immunocontraception, and is thought to be due to genetic differences among individual animals.

There were less estrus events observed in the GnRH-treated deer as compared to the control deer, both groups were observed to have a mean of less than one estrus event per season. It is obvious that some estrus events were missed since all control deer became pregnant. The PZP contracepted deer in a former study ${ }^{2}$ were observed to have a mean of 3.6 estrus events over a period of 98 days. With the normal rutting period of 44 days at the facility, it was important to note that the GnRH immunocontraceptive treatment did not increase the length of rut. This is an important consideration since it is believed that increased deer/car collisions are associated with the rutting season.

Infertility was directly related to anti-GnRH titers above 64,000 with infertility lasting up to 2 years without boosting. As the antibody titer dropped the deer became fertile again, usually having one fawn the first year.

Numerous studies indicate GnRH immunocontraception results in immunocastration of both sexes, that is, the drop in biologically active GnRH reduces LH and FSH release, and consequently reduces gonadal steroid production. The deer remains infertile as long as the antibody neutralizes the endogenous GnRH. Norway rat ${ }^{15}$ studies demonstrated this immunocontraceptive effect in both sexes, which lasted for the life expectancy of the rat in the field (approximately 1 year). In the present 4 year study, we found that the contraceptive effect may last up to 2 years without boosting.

Interestingly, if the antibody titer is sufficiently high, the doe does not appear to ovulate or produce a functioning corpus luteum as evidenced by the low progesterone level during the period when ovulation should be occurring. This study also demonstrates that some does with low antibody titers apparently release enough $\mathrm{LH}$ to ovulate and conceive, but the progesterone produced by the corpus luteum is not enough to maintain the pregnancy.

Although the placenta serves as a source of progesterone, the placental contribution of progesterone in early pregnancy is not sufficient to maintain pregnancy without the progesterone from the corpus luteum. ${ }^{26}$ In studies by Plotka et al. ${ }^{25}$, ovariectomy of deer at 100 or 156 days of gestation reduced progesterone levels and resulted in termination of pregnancy. These experiments demonstrate that the ovaries are the principal source of progesterone through the first 
156 days of the normal 200 day gestation in the white-tailed deer, and that ovarian progesterone is essential for maintenance of pregnancy. It appears, therefore, that antibody neutralization of endogenous $\mathrm{GnRH}$ affects the production of ovarian progesterone by the corpus luteum needed for maintenance of pregnancy. Russell ${ }^{27}$ found that the serum progesterone concentration was an excellent indicator of early pregnancy. He used the drop in progesterone as evidence of embryonic mortality in lactating caribou that were in poor condition.

\section{Male Deer}

The GnRH-treated bucks in our study demonstrated characteristics similar to those of a castrated male with a resultant testicular regression. This same testicular regression was observed by Oonk et al. ${ }^{16}$ in GnRH-treated male pigs, and in our GnRH-treated male Norway rats. ${ }^{15}$ Treated bucks shared feeders with control females that were in estrus, but had little interest in sexual activity. They were not considered a competitive threat to the dominant buck and were ignored by it. In the normal buck, the rise in FSH and LH in the fall governs testicular sperm production and testosterone secretion, which in turn modulates muscle and antler development. The slow growth of the velvet antler in spring is consistent with the low level of testosterone present throughout the spring and summer. The rapid antler growth in the latter half of summer and shedding of velvet in September is consistent with a rapid rise in testosterone in the same time period in response to the shortened day length. The shedding of the antlers in February or March corresponds to a drop in testosterone in response to the increasing day length. Sperm production begins in mid-August and extends through March, with peak sperm production in mid-November and dropping in half by mid-December. ${ }^{5}$

If a buck is castrated while its antlers are in velvet, they are retained, and do not harden or lose their velvet. An animal castrated after the velvet is shed loses its antlers within a week and the antlers regrow the next year. However, the antlers will remain in velvet the second year and will not have the normal spring drop. ${ }^{5}$ The response of the bucks in this study to the GnRH vaccine mimics that of physical castration, and therefore is appropriately called immunocastration.

\section{Conclusion}

In this study, we have shown that KLH-GnRH vaccine is an effective immunocontraceptive or an immunocontragestive vaccine in the white-tailed deer.
Fawning rates were reduced by $88 \%$ when GnRHtreated does were paired with fertile bucks. The GnRH conjugate produced high antibody titers resulting in infertility for up to 2 years without boosting. It appears that this vaccine is reversible; that is, when the antibody titer drops, fertility is restored. Furthermore, the deer could be boosted again, causing the deer to again become infertile. There was little difference in the observed behavioral effects between the GnRH-treated does and the control does. GnRHtreated bucks, on the other hand, lost most sexual interest in the does coming into estrus. Early antler loss and the absence of antler hardening may be considered negative side effects of treating bucks. The study also shows that the GnRH vaccine reduces the reproductive behavior associated with the rutting season. Given these characteristics, a GnRH vaccine may be acceptable to address the increasing problem of deer/car accidents which appear to increase with increased deer movements associated with the breeding season.

GnRH vaccination may have limited application for immunosterilizing bucks in field situations because of its effect on antler growth; however, it may be useful in parks or non-huntable populations where the aggressive behavior of the buck in the fall is an undesirable safety concern. Assuming an oral GnRH vaccine can be developed, ${ }^{28}$ it would also be necessary to consider species specificity in the delivery of the bait, since GnRH is not species specific. Additionally, if the effects on antler growth were a concern, a feeder that prevented antlered bucks from getting into the bait could be used to selectively contracept does in the field.

\section{REFERENCES}

1. McShea WJ, Monfort SL, Hakim S, Kirkpatrick J, Liu I, Turner JW, Chassy L, Munson L: The Effect of Immunocontraception on the Behavior and Reproduction of White-Tailed Deer. J Wildl Manage 1997; 61:560-569.

2. Miller LA, John BE, Killian GJ: Long-term effects of PZP immunization on reproduction in white-tailed deer. Vaccine 1999; 18:568-574.

3. Turner JW, Liu I, Kirkpatrick JF: Remotely delivered immunocontraception in captive white- tailed deer. J Wildl Manage 1992; 56:154-157.

4. Verne LJ, Ullrey DE, Physiology and Nutrition. In: White-tailed Deer, Ecology and Management. Ed. Hall, L. K., Stockpile Books 1984; pp. 91-118.

5. Lincoln GA, Biology of Seasonal Breeding in Deer. In: The Biology of Deer. Ed. Brown, R. D., Springer-Verlag, New York, 1992; Chap 131.

6. Goss RJ: Photoperiodic control of antler cycles in deer; II. Alteration in amplitude. J Exp Zool 1969; 17:223234. 
7. Talwar GP: Immunobiology of GonadotropinReleasing Hormone. J Steroid Biochem 1985; 23:795800.

8. Awoniyi CA, Reece MS, Hurst BS, Faber KA, Chandrashekar V, Schlaff WD: Maintenance of sexual function with testosterone in the gonadotropin-releasing hormone immunized hypogonadotropic infertile male rat. Biol Reprod 1993; 49:1170-1176.

9. Ladd A, Tsong YY, Walfield AM, Thau R: Development of an Antifertility Vaccine for Pets Based on Active Immunization against Luteinizing Hormone-Releasing Hormone. Biology of Reproduction 1994; 51:1076-1083.

10. Adams TE, Adams BM: Feedlot performance of steers and bulls actively immunized against gonadotropin-releasing hormone. J Anim Sci 1992; 70:691-698.

11. Robertson IS: Effect of immunological castration on sexual and production characteristics in male cattle. Vet Rec 1982; III:529-531.

12. Rabb MH, Thompson DL Jr, Barry BE, Colborn DR, Hehnke KE, Garza F Jr: Effects of active immunization against GnRH on LH, FSH and Prolactin storage, secretion and response to their secretagogues in pony geldings. J Anim Sci 1990; 68:3322-3329.

13. Schanbacher BD: Response of ram lambs to active immunization against testosterone and luteinizing hormone-releasing hormone. Am J Physiol 1982; 242:201205.

14. Meloen RH, Turkstra JA, Lankhof H, Puijk WC, Schaaper WMM, Dijkstra G, Wensing CJG, Oonk RB: Efficient immunocastration of male piglets by immunoneutralization of GnRH using a new GnRH-like peptide. Vaccine 1994; 12:741-746.

15. Miller LA, Johns BE, Elias DJ, Crane KA: Comparative efficacy of two immunocontraceptive vaccines. Vaccine 1997; 15:1858-1862.

16. Oonk HB, Turkstra JA, Schaaper W, Erkens MM, Schuitemaker-deWeerd $\mathrm{MH}$, van Nes A, Verheijden JHM, Meloen RH: New GnRH-like peptide construct to optimize efficient immunocastration of male pigs by immunoneutralization of GnRH. Vaccine 1998; 16:1074-1082.

17. Ferro VA, O'Grady JE, Notman J, Stimson WH: An investigation into the immunogenicity of a GnRH analogue in male rats: a comparison of the toxicity of various adjuvants used in conjunction with GnRH-glycys. Vaccine 1996; 14:451-457.

18. Ferro VA, Stimson WH: Investigation into suitable carrier molecules for use in an anti-gonadotrophin releasing hormone vaccine. Vaccine 1998; 16:1095-1102.

19. Ladd A, Tsong YY, Lok J, Thau RB: Active Immunization Against LHRH: 1. Effects of Conjugation Site and Dose. American Journal of Reproductive Immunology 1990; 22:56-63.

20. Morrison CA, Fishleigh RV, Ward DJ, Robson B: Computer aided design and physiological testing of a LHRH analogue for 'adjuvant-free' immunocastration. FEBS Letters 1987; 214:65-73.

21. Canon SK, Bryant FC, Bretzlaff KN, Hellman KC, Hellman JM: Pronghorn pregnancy diagnosis using trans-rectal ultrasound. Wildlife Society Bulletin 1997; 25:832-834.

22. Plotka ED, Deal US, Schmoller GC, Karns PD: Reproductive steroids in the white-tailed deer (Odocoileus virginianus borealis) I. Seasonal changes in the female. Bio Reprod 1977a; 16:340-343.

23. Plotka ED, Deal US, Verme LJ, Ozoga JJ: Reproductive steroids in the white-tailed deer (Odecoileus Virginianus borealis). II. Progesterone and estrogen levels in peripheral plasma during pregnancy. Biol Reprod 1977b; 17:78-83.

24. Plotka ED, Deal US, Verme LJ, Ozoga JJ: Reproductive steroids in deer III. Luteinizing hormone, estradiol and progesterone around estrus. Biol Reprod 1980; 22:576581 .

25. Plotka ED, Deal US, Verme LJ, Orzoga JJ: Reproductive steroids in white-tailed deer. IV. Origin of progesterone during pregnancy. Biology of Reproduction 1982; 26:258-262.

26. Catchpole HR, Hormonal Mechanisms in Pregnancy and Parturition. In Reproduction in Domestic Animals 1991; 4th Ed., 361-83.

27. Russell DE, Gerhart KL, White RG, Van De Wetering D: Detection of Early Pregnancy in Caribou: Evidence for Embryonic Mortality. J Wildl Manage 1998; 62:1066-1075.

28. Miller LA, Delivery of immunocontraceptive vaccines for wildlife management. In: Contraception in Wildlife Management, Ed. J. S. Wintermute, USDA/APHIS Tech. Bull. No. 1853, Washington DC, 1997; pp 49-58 